\title{
Searching for the effects of the May-June 2012 Emilia seismic sequence (northern Italy): medium-depth deformation structures at the periphery of the epicentral area
}

\author{
Lisa Borgatti ${ }^{1,{ }^{\star}}$, Antonio Edoardo Bracci $^{2}$, Stefano Cremonini ${ }^{3}$, Giovanni Martinelli ${ }^{4}$ \\ ${ }^{1}$ Università di Bologna, Dipartimento di Ingegneria Civile, Ambientale e dei Materiali (DICAM), Bologna, Italy \\ ${ }^{2}$ Geoexploration s.r.l., Forli, Italy \\ ${ }^{3}$ Università di Bologna, Dipartimento di Scienze della Terra e Geologico-Ambientali, Bologna, Italy \\ ${ }^{4}$ Agenzia Regionale Prevenzione e Ambiente (ARPA) dell'Emilia Romagna, Sezione di Reggio Emilia, Reggio Emilia, Italy
}

\section{Article history}

Received July 22, 2012; accepted August 27, 2012.

Subject classification:

Emilia 2012 earthquake, Seismic effect, Faulting, Seismic reflection survey.

\section{Introduction}

In 2012, a seismic sequence occurred in the lowlands of the Emilia-Romagna Region (northern Italy), between the borders of the Modena, Ferrara and Bologna Provinces. It consisted of seven mainshocks $\left(5.9>\mathrm{M}_{\mathrm{L}}>5\right)$ that were recorded between May 20 and 29, 2012 [INGV 2012a] and 2,200 minor earthquakes [INGV 2012b]. An interferometric analysis [Bignami et al. 2012, Salvi et al. 2012, this volume] highlighted three main deformation areas, each of which was $12 \mathrm{~km}$ wide (from $S$ to $\mathrm{N}$ ) and $10 \mathrm{~km}$ to $20 \mathrm{~km}$ long in an ESEWNW to E-W direction, thus affecting an area of about $600 \mathrm{~km}^{2}$ (Figure 1). Field and aerial geological surveys recorded numerous surficial effects, such as: (i) sediment liquefaction [Crespellani et al. 2012]; (ii) localized ground fissures resembling surficial faulting [Fioravante and Giretti 2012] (Figure 2); (iii) groundwater levels rising up to $400 \mathrm{~cm}$ above the local ground level in phreatic wells during the mainshocks (lower values were observed in confined aquifers); and (iv) dormancy of previously known sinkholes [Borgatti et al. 2010, Cremonini 2010a, and references therein]. Some of the observed surface phenomena were previously recorded as coseismic effects during the earthquakes of Ferrara (1570) and Argenta (1624) [Boschi et al. 1995, Galli 2000], together with the early rising of the water level of the Po River in the Stellata section.

Apart from more than 700 liquefaction phenomena [Bertolini and Fioroni 2012, this volume] that were generated by shallow groundwater interactions with sandy fine sediments within 10-20 meter depth [Gruppo di Lavoro Liquefazione 2012], no significant tectonic faulting of the ground surface was detected [Galli et al. 2012].

In particular, there was no evidence of reactivation of previously reported tectonically generated faults in the area [e.g., Pellegrini and Vezzani 1978] or of possibly tectonically induced ground fissuring phenomena, like sinkholes [Bonori et al. 2000, Borgatti et al. 2010, and references therein]. To investigate the presence of possible, still undocumented, medium-depth fracturing and faulting phenomena, a high resolution seismic survey was carried out close to the site affected by the most significant ground fissure [Abu Zeid et al. 2012, this volume] and sand liquefaction phenomena [Gruppo di Lavoro Liquefazione 2012], on the outskirts of the village of San Carlo, near Sant'Agostino (Ferrara Province).

\section{Geological and geomorphological setting}

The study area is located on the buried front of the Apennine chain, which is characterized by a series of thrustand-folds that resulted from the collision between the European (Corso-Sardinian block) and Adria plates. Since the Oligocene, the related chain foredeep is still in the process of evolving, according to a NE-directed compression that is causing external crustal shortening. At the end of the Lower Pleistocene, the chain began to grow, shaping the emerged mountain area of today, as a consequence of mantle wedging and crust rollback processes [Picotti and Pazzaglia 2008]. In the foredeep, the marine environment developed up to the beginning of the Middle Pleistocene, then it turned towards low marine to transitional conditions (Marine Quaternary Emilia-Romagna Subsyntheme), which finally (last major regional unconformity) became mainly continental during the Upper Pleistocene to Holocene (lower [AEI] and upper [AES] Emilia-Romagna synthemes). The minor unconformity separating the AEI and AES dates back to about $450 \mathrm{kyr}$ BP [Boccaletti et al. 2010]. The continuous tectonic development of 


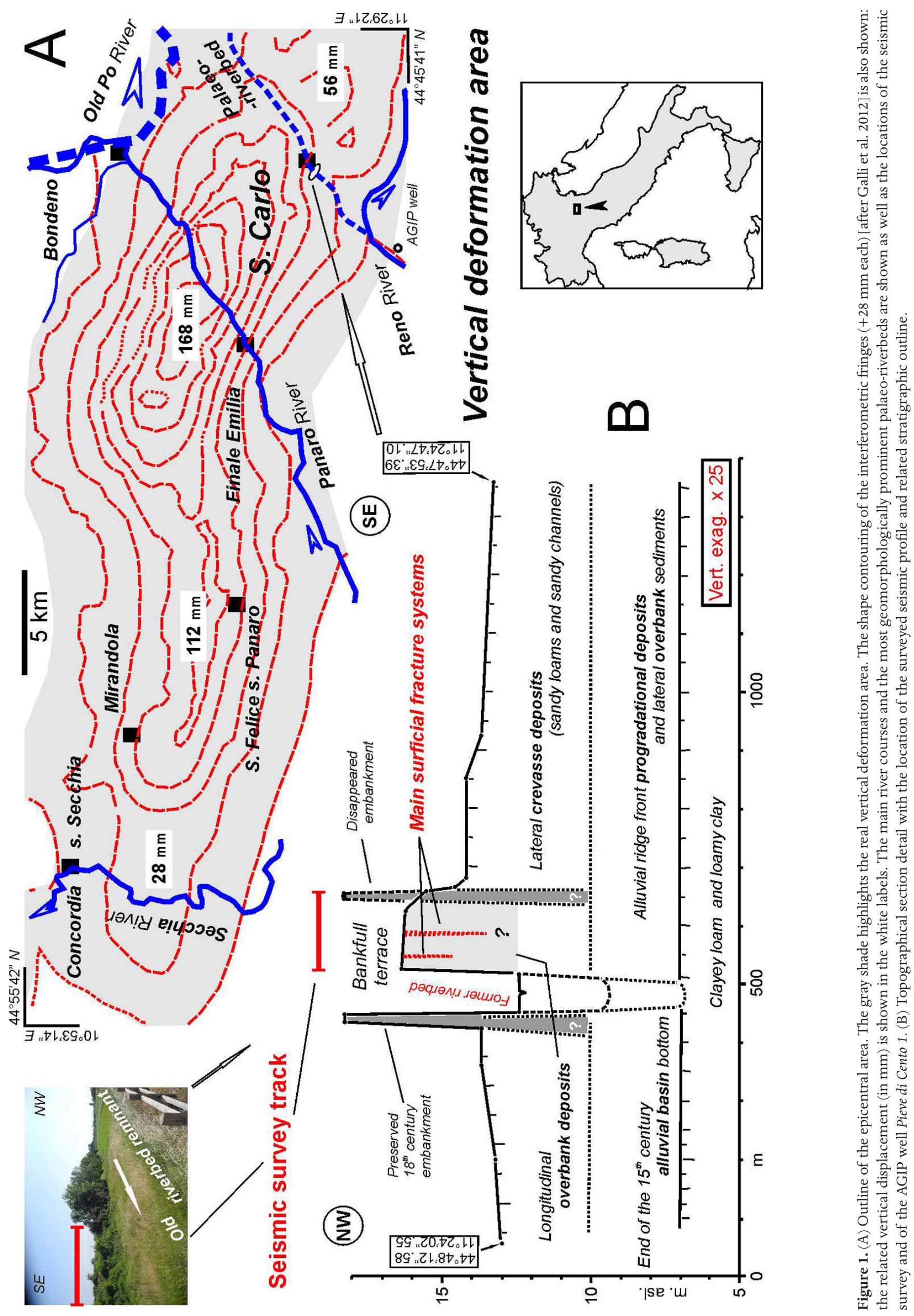



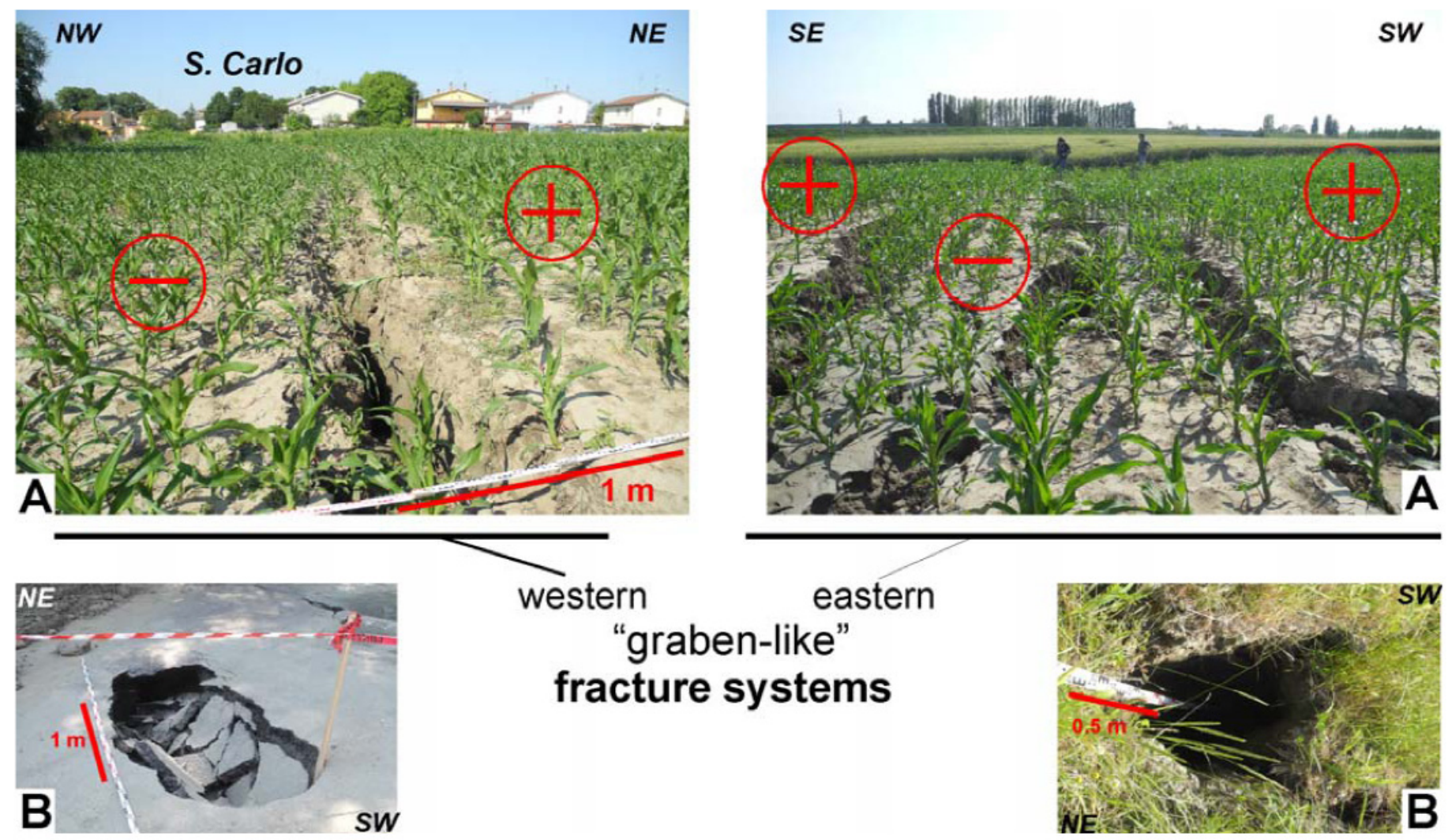

eastern

"graben-like"

fracture systems

Figure 2. The graben-like surficial fracturing (A) at the San Carlo site, with small-scale sinkholes (B) at its tip. The location is the same as the surveyed seismic profile (see Figure 1).

the buried thrusts (Dorsale Ferrarese and Pieghe Romagnole) along its long axis (over a distance of $200 \mathrm{~km}$ ) varies from place to place, in the time and depth domains, and deformed the Emilia-Romagna syntheme locally, affecting also the AES. The arc sector of the buried front involved in the May 2012 seismic sequence (almost $50 \mathrm{~km}$ long) is located in a centralwestern reach of the chain front, where it becomes more complex, displaying a double alignment of folds. Although published data are not available for the San Carlo area, the lower limit of the AEI could lie at an equivalent depth of about $360 \mathrm{~m}$ [ISPRA and R.ER 2009, sheet 2: profile F].

A medium depth stratigraphic outline for this area (Figure 3) can be obtained by the benchmark borehole Pieve di Cento 1 that is located $6 \mathrm{~km} \mathrm{SW}$ of San Carlo (Figures 1A, 3). It shows the top of the Pliocene deposit at about $315 \mathrm{~m}$ in depth [ENI 1972], whereas the overlying Pleistocene deposits can only be detailed according to an equivalent stratigraphic section [ISPRA and R.ER 2009, sheet 2: profile F]. Bearing in mind that the well lies near the top of an anticline structure after the projection of the San Carlo location, we can obtain the following stratigraphic outline (Figure 3). If the average ground elevation is kept as a reference, the thickness of the Holocene deposit $\left(\mathrm{AES}_{8}\right)$ can be estimated as in the order of $22 \mathrm{~m}$ to $25 \mathrm{~m}$. The so-called $\mathrm{AES}_{7}$ deposits of the last glacial age (clays and rare channel sediments) reach to about $80 \mathrm{~m}$ in depth. Between $80 \mathrm{~m}$ and $120 \mathrm{~m}$, the interglacial (RissWuerm) Po River channel sands and basinal fines $\left(\mathrm{AES}_{6}\right)$ are recorded. There are fluvio-deltaic or shelf Po River sands
(AES undif) down to $216 \mathrm{~m}$ to $220 \mathrm{~m}$, and finally pro-delta and shelf clays and loams (lower AE) reach to $320 \mathrm{~m}$ in depth, where the saltwater/freshwater boundary probably lies. At that depth, the base of the entire sequence is already gently folded [ISPRA and R.ER 2009, sheet 2] according to the general folding of the multiple and complex structural high that characterizes the outermost edge of the buried Apennine chain front [CNR 1992, Cerrina Feroni et al. 2002].

The geomorphological setting is characterised by fluvial activity and historical paleo-riverbeds. In particular, San Carlo village lies atop the bankfull terrace (18 $\mathrm{m}$ a.s.l.) of a paleo-bed of the Reno River that dates back to the Late Middle Ages (1460-1461). The river began to abandon this bed sector in the year 1738 (Annegati crevasse), and definitely ceased around the year 1751 (Panfilia crevasse) [Cremonini and Scarin 2007]. Because of this recent and sudden avulsion, the old riverbed is still well preserved and open (12.5 $\mathrm{m}$ a.s.1.); the external field ground lies at $13.3 \mathrm{~m}$ a.s.l. whereas the lateral bank is about $4 \mathrm{~m}$ higher (16.4 $\mathrm{m}$ a.s.1.) (Figure 1B). Due to the artificially controlled river progradation into the Late Medieval clayey alluvial basin, a local sedimentary sequence can be recognized, showing about $3 \mathrm{~m}$ of clayey loam and sand of the progradational front of the alluvial ridge. A further $3 \mathrm{~m}$ of lateral crevasse or incipient riverbed sands up to the field ground are finally covered by about $4 \mathrm{~m}$ of overbank deposits constrained by the old longitudinal embankment system. The sand belonging to the channel facies has a thickness of about $6 \mathrm{~m}$ [Cremonini 1981]. 


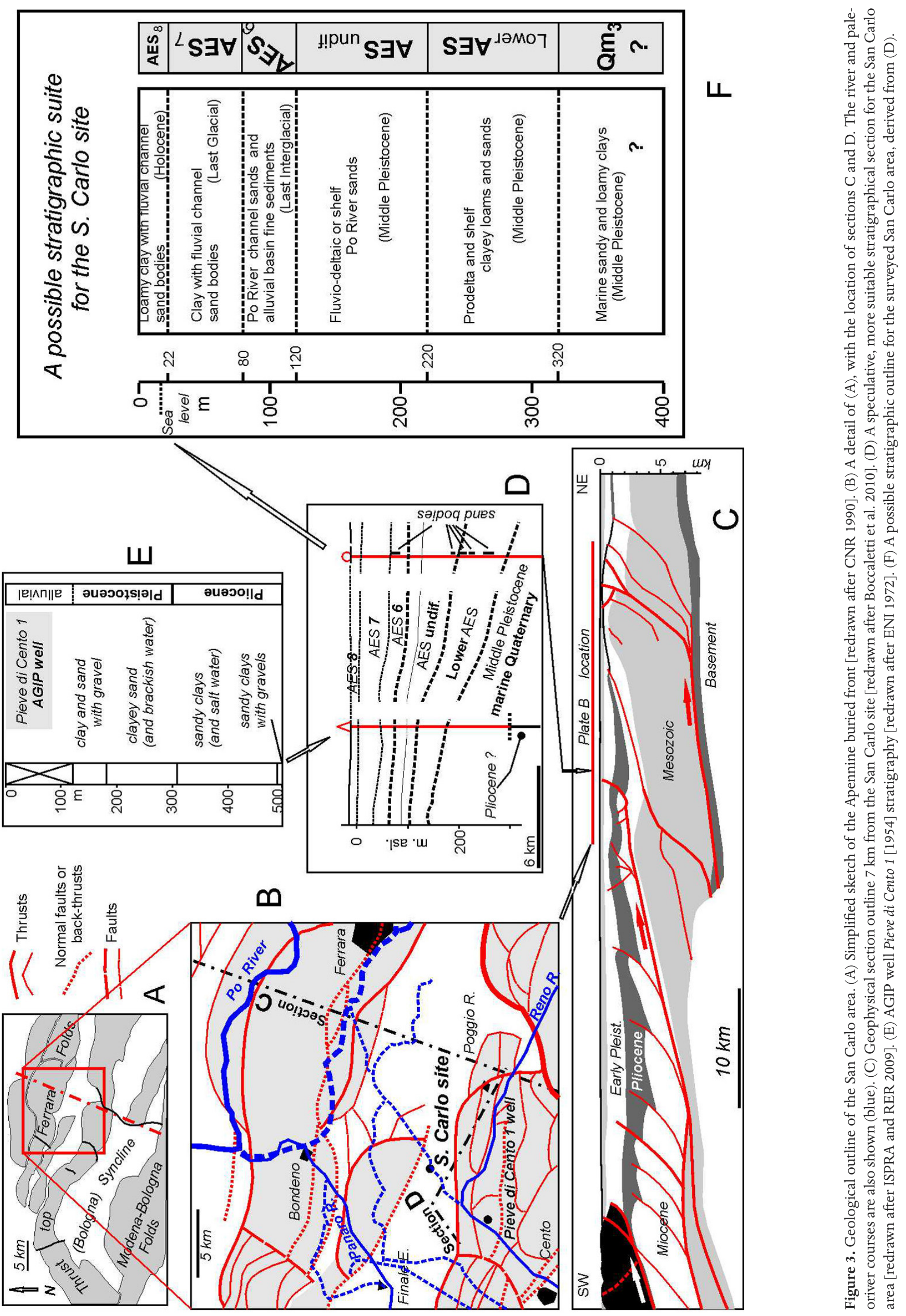



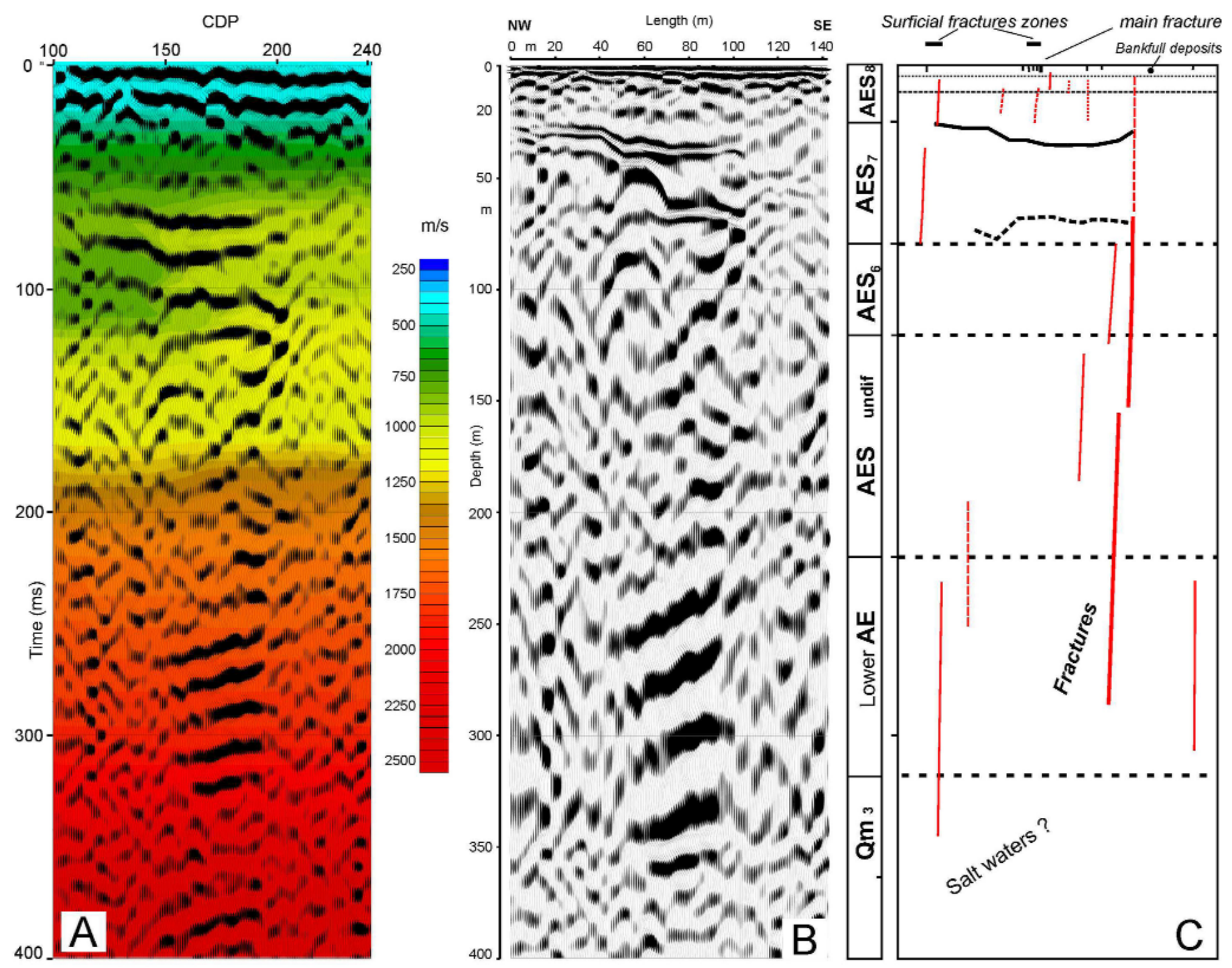

Figure 4. The surveyed seismic section. The velocity field (A): the stack section and the time/ depth converted section (B) are shown. Sketch (C) suggests the possible interpretation of (B), mainly in terms of main faults / fractures. On the left of (C), the labels of the essential stratigraphy (see text) are recorded.

As a consequence of the ground shaking caused by the first mainshock (M 5.9, May 20, 2012), at the top of the right old river bank a parallel-coupled small graben-like system of fractures developed, with each 'graben' being about $3 \mathrm{~m}$ to 5 $\mathrm{m}$ in size, with the inner limb lowered by about $50 \mathrm{~cm}$ to 60 $\mathrm{cm}$, with the border fractures up to $2.7 \mathrm{~m}$ deep and $0.5 \mathrm{~m}$ wide. Sporadic sinkholes were generated at the tip of some of the fractures (Figure 2). These are the only sinkholes known to have developed in the epicentral area.

\section{Methods}

A reflection seismic survey was performed as a transect crossing the wide right-hand terraced bank of the ancient river course, at an almost constant elevation of $16.4 \mathrm{~m}$ a.s.l. (Figure 1). The seismic line length was $142 \mathrm{~m}$. Seventy-two geophones were used, with 2-m spacing. The chosen array was 1 geophone/ channel, with frequency $10 \mathrm{~Hz}$. The energy source was an $8 \mathrm{~kg}$ sledge-hammer impacting on a nylon plate, to reduce the effect of air blast noise. To complete a record, at least 3 blows were used for each shot point. The shot point location was at every geophone location, starting from geophone 1 through to geophone 72 , thus resulting in a coverage of $3600 \%$ in the centre of the section. A 72 CHS Geometrics Geode recording instrument with 64,000 sam$\mathrm{ples} /$ channel was used, adopting a record length of $0.5 \mathrm{~s}$. The sample interval was $0.125 \mathrm{~ms}$, with filters out. The Moscow State University RadExPro QC configuration [MSU 2011] was adopted as the processing software, which involved the main subsequent processing steps of: data input, geometry assignment, amplitude corrections, deconvolution, trace interpolation, filtering, velocity analysis (using the 'interactive analysis of stacking velocities' option), NMO correction, CDP stacking, time-depth conversion, and F-K migration, which really improved the seismic imaging.

\section{Results}

Figure 4 shows the velocity field and the migrated section. No scale exaggeration is used. The horizontal resolution was $1 \mathrm{~m}$ (half way between the shot point and the geophones), whereas the vertical resolution varied from $1 \mathrm{~m}$ 
BORGATTI ET AL.
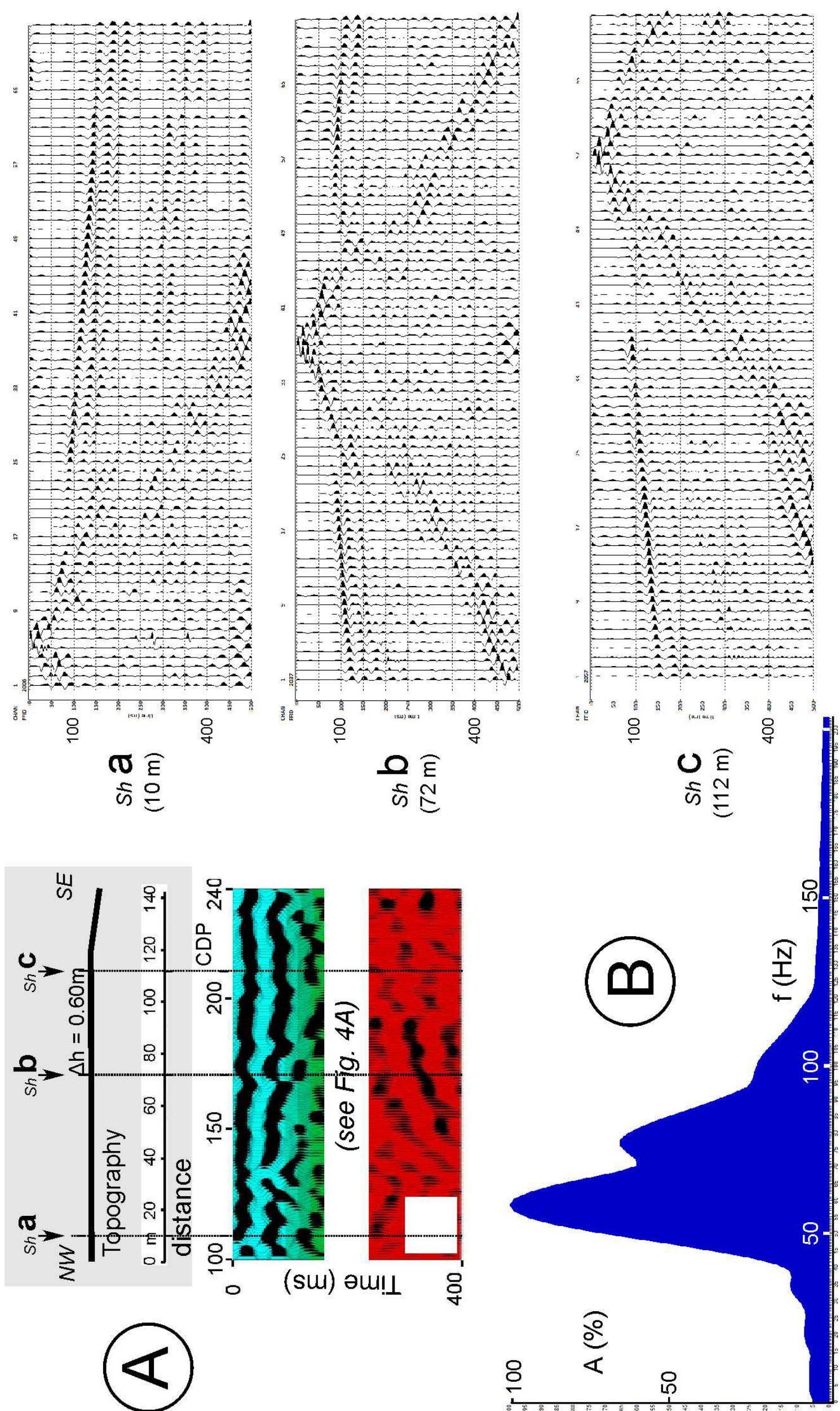
to $8 \mathrm{~m}$, depending on the reflected signal frequency content and velocity (according to the equation: Resolution $=\mathrm{V} / 4 \mathrm{f}$ ). Most of the reflectors are sharp. Figure 5 shows a shot gather and the frequency spectrum of the seismic waves reflection, to better check the signal quality. A signal attenuation appears at around $110 \mathrm{~m}$ to $130 \mathrm{~m}$ horizontal distance. The unusual aspect ratio of the section and its resolution can generate some difficulties in the interpretation of the general pattern, which might be expected to show mainly a nearly horizontal bedding. The general pattern is instead extremely complex. The uppermost part (Holocene) is clearly disturbed by a series of almost vertical disruptions, apparently involving the whole thickness of the unit. The first two reflectors are the equivalent of the bankfull terrace deposits. Even if the vertical resolution is not yet adequate, in this part of the section the disturbances are clear and there appears to be a good fit between them and the surficial fractures. The Late Pleistocene-Holocene stratigraphic boundary is marked by two coupled reflectors lying at $25 \mathrm{~m}$ to $30 \mathrm{~m}$ (i.e., $21 \mathrm{~m}$ to $26 \mathrm{~m}$ below the mean ground level), and lowered in the central part by ca. $6 \mathrm{~m}$ to $7 \mathrm{~m}$. A second, irregular couplet lies at $60 \mathrm{~m}$ to $70 \mathrm{~m}$, which probably represents the AES6/ AES7 boundary [ISPRA and R.ER. 2009]. At depth, the reflector convolutions are partly due to a series of subvertical discontinuity planes (fractures or faults, often characterized by clear vertical displacement), such as the one lying at $100 \mathrm{~m}$ to $105 \mathrm{~m}$ towards the East. A suggestion leading towards a pockmark morphology is exerted by some recurrent V-shaped forms, such as that at $40 \mathrm{~m} \mathrm{E}$, although these are probably just artefacts arising from a local scattering phenomena, instead of diffractions, which usually characterise faults in rocky environments.

\section{Discussion}

Within the framework of the Emilia geological and hydrogeological setting [Pellegrini et al. 1976, ISPRA and R.ER 2009], previous studies have shown an anomalous concentration of $\mathrm{NaCl}$ in soils in the area affected by the seismic sequence [Puppini et al. 1955, Calzolari and Ungaro 2011]. Martinelli et al. [1998, and references therein] and Conti et al. [2000] described the occurrence of brackish groundwater in the same area, possibly attributable to deeper geological units. Scicli [1972], Martinelli [2007], and Martinelli et al. [2012] also discuss the origins of the deep fluid emissions in this area. Cassano et al. [1986] reported that there are faults in Miocenic and pre-Miocenic layers of the Po Valley that can cross, in principle, Quaternary deposits [see also Castellarin et al. 2006, Cremonini 2010a, Cremonini 2010b, Cremonini et al. 2010, and references therein]. Thus, geophysical surveys should reveal the eventual fault structures involved in the tectonic pumping phenomena [e.g., Sibson, 1981] of deeper Mio-Pliocenic sediments, and be able to induce geochemical anomalies in groundwater hosted in the Quaternary sediments and saline soil anomalies recorded by Puppini et al. [1955] and Calzolari and Ungaro [2011]. Data obtained in the San Carlo seismic survey show the possible faulting/fracturing at least in the interval from $0 \mathrm{~m}$ to $400 \mathrm{~m}$ in depth. No seismic profiles that were obtained during oil prospecting are available in this area to date, and thus caution should be taken in the data interpretation. In particular, the observed geometric features might be tectonically originated or due to gas and water uprising, as well as to gravitative phenomena. Indeed, some of the most surficial features might be related to liquefaction-induced lateral spreading [Obermeier et al. 2001]. This is defined as the finite, lateral displacement of gently sloping ground (mild slopes of $0.3 \%$ to $5 \%$ underlain by loose sands and a shallow water table; see Bartlett and Youd [1992]), as a result of pore pressure build-up or liquefaction in a shallow underlying deposit during an earthquake. On this issue, it is still unclear why the local response to the seismic shaking was so strong $20 \mathrm{~km}$ from the May 20, 2012, epicenter; at the same time, along many other riverbeds and paleo-riverbeds that cross the epicentral area (the Secchia, Panaro and Reno rivers), the recorded surficial effects were not so striking.

The whole compressive setting of the buried Apennine outer arc that is highlighted by the Emilia seismic sequence [Galli et al. 2012] shows the triggering of both longitudinal and transverse structural elements of minor order all along the buried arc, which are partly still not documented in detail [INGV 2012c]. The eastern wing of the epicentral area where San Carlo also lies is constituted by two relative structural highs, with an interposed small syncline (Figure 3). If the Ramsey stress model is adopted [Ramsey 1967, Carminati et al. 2010], a series of longitudinal fractures develop along the top of the thrust folds in the uppermost hundreds of meters, and contemporary tension structures can appear along the syncline axis. Thus, the medium depth fractures found at San Carlo might be extradossal structures. Furthermore, the observed fractures (Figure $4 \mathrm{C}$ ) might also be related to a possible transverse shear zone. Indeed, the interferometric survey [Galli et al. 2012, Bignami et al. 2012, Salvi et al. 2012] shows a 1$\mathrm{km}$-wide, sharp-cut band (evidence of coherence loosening) in the eastern wing of the uplifted epicentral area, almost following the path of the old Reno riverbed, particularly near San Carlo. This separates (Figure 1A) a western area that is characterized by a higher vertical displacement rate $(168 \mathrm{~mm})$, from an eastern area that has a lower rate $(56 \mathrm{~mm})$. An alternative model might be to link the existence of the medium depth fault to sediment compaction, which is still ongoing along the thrust sides [Carminati et al. 2010]. Ultimately, the possible existence of faulting phenomena that can cross Quaternary layers should be considered. 


\section{Conclusions}

The analysis of the seismic survey performed at the San Carlo site shows that the whole local sedimentary column is cut by a set of faults/fractures. The observed medium-depth geometric features might have had a role in the development of surface fracturing that occurred in the surveyed area after the May 20, 2012, event. In the near future, only a few geological pieces of evidence of coseismic surface phenomena will be preserved, and the San Carlo fracture system should be better investigated, to understand whether it should be considered as a mere site-effect due to the 4-m-high river bank surficial morphology, or whether other possible conditioning factors might exist.

Acknowledgements. Our thanks go to Geoexploration Srl (namely Giuseppe Mainardi and Diego Peraccini), for cooperation in the field survey and the data processing. Thanks are also due to anonymous reviewers for their thoughtful suggestions, which contributed to the improving of the overall quality of our manuscript.

\section{References}

Abu Zeid, N., S. Bignardi, R. Caputo, G. Santarato and M. Stefani (2012). Electrical resistivity tomography investigation of coseismic liquefaction and fracturing at San Carlo, Ferrara Province, Italy, Annals of Geophysics, 55 (4); doi:10.4401/ag-6149.

Bartlett, S.F., and T.L. Youd (1992). Empirical analysis of horizontal ground displacement generated by liquefaction-induced lateral spreads, Technical Report NCEER-92-0021, National Center for Earthquake Engineering Research, Buffalo, NY, USA.

Bertolini, G., and C. Fioroni (2012). Aerial inventory of surficial geological effects induced by the recent Emilia earthquake (Italy): preliminary report, Annals of Geophysics, 55 (4); doi:10.4401/ag-6113.

Bignami, C., P. Burrato, V. Cannelli, M. Chini, E. Falcucci, A. Ferretti, S. Gori, C. Kyriakopoulos, D. Melini, M. Moro, F. Novali, M. Saroli, S. Stramondo, G. Valensise and P. Cannoli (2012). Coseismic deformation pattern of the Emilia 2012 seismic sequence imaged by Radarsat-1 interferometry, Annals of Geophysics, 55 (4); doi:10.4401/ ag-6157.

Boccaletti, M., G. Corti and L. Martelli (2010). Recent and active tectonics of the external zone of the northern Apennines (Italy), Int. J. Earth Sci.; doi:10.1007/s00531010-0545-y.

Bonori, O., M. Ciabatti, S. Cremonini, R. Di Giovambattista, G. Martinelli, S. Matrizzi, G. Quadri, E. Rabbi, P.V. Righi, S. Tinti and E. Zantedeschi (2000). Geochemical and geophysical monitoring in tectonically active areas of the Po Valley (northern Italy). Case histories linked to gas emission structures, Geogr. Fis. Din. Quat., 23, 3-20.

Borgatti, L., E. Bianchi, G. Bonaga, G. Gottardi, A. Landuzzi, G. Marchi, A. Mastrangelo, S. Rodorigo, G. Vico and L.
Vittuari (2010). Fenomeni di sprofondamento del piano di campagna in Pianura Padana: il ruolo del contesto geologico, geomorfologico e geotecnico, In: $2^{\circ}$ Workshop internazionale "I Sinkholes Gli sprofondamenti catastrofici nell'ambiente naturale ed in quello antropizzato" (Roma, 3-4 dicembre 2009), ISPRA, Roma, 181-201.

Boschi, E., G. Ferrari, P. Gasperini, E. Guidoboni, G. Smriglio and G. Valensise (1995). Catalogo dei forti terremoti in Italia dal 461 a.C. al 1980, INGV-SGA, Bologna, 973 pp.

Calzolari, C., and F. Ungaro (2011). Carta della salinità dei suoli della Pianura Emiliano Romagnola - strato 50-100 $\mathrm{cm}$, Regione Emilia-Romagna, $18 \mathrm{pp}$.

Carminati, E., D. Scrocca and C. Doglioni (2010). Compaction-induced stress variations with depth in an active anticline: northern Apennines, Italy, J. Geophys. Res., 115, B 02401; doi:10.1029/2009JB006395.

Cassano, E., L. Anelli, R. Fichera and V. Cappelli (1986). Pianura Padana. Interpretazione integrata di dati geologici e geofisici, Centro Stampa AGIP, $73^{\circ}$ Congresso Società Geologica Italiana (Roma, 29 Sett.-4 Ott. 1986), 27 pp.

Castellarin, A., E. Rabbi, S. Cremonini, L. Martelli and F. Piattoni (2006). New insights into the underground hydrology of the eastern Po Plain (northern Italy), B. Geofis. Teor. Appl., 47, 271-298.

Cerrina Feroni, A., L. Martelli, P. Martinelli, and G. Ottria (2002). Carta geologico-strutturale dell'Appennino Emiliano-Romagnolo in scala 1:250.000, Regione Emilia-Romagna - C.N.R. Pisa, S.EL.CA., Firenze.

CNR (1992). Structural Model of Italy, 1:500,000. Progetto Finalizzato Geodinamica S.P. 5, Quaderni de La Ricerca Scientifica n. 114. S.EL.CA., Firenze.

Conti, A., E. Sacchi, M. Chiarle, G. Martinelli and G.M. Zuppi (2000). Geochemistry of the formation waters in the Po Plain (northern Italy): an overview, Appl. Geochem., 15, 51-65.

Cremonini, S. (1981). Evoluzione morfologica ed idrografica della pianura bolognese tra Reno ed Idice, Tesi di Laurea in Scienze Geologiche, Università di Bologna, relatore: prof. M. Ciabatti, AA. 1979-80, 307 pp. (graduation thesis, unpublished).

Cremonini, S., and M.L. Scarin (2007). Osservazioni stratigrafiche e considerazioni paleoambientali preliminari nell' area di Galliera (Bologna). Una prospettiva di ricerca integrata nei rapporti tra insediamento e paleoambiente nella pianura d'età medievale, In: P. Galetti (a cura di), Una terra di confine. Storia e archeologia di Galliera nel medioevo, Bologna, 163-220.

Cremonini, S. (2010a). A preliminary overview of sinkholes in the Emilia-Romagna Region (Italy), In: Atti del $2^{\circ}$ Workshop Internazionale sui fenomeni di sinkhole I sinkholes. Gli sprofondamenti catastrofici nell'ambiente naturale ed in quello antropizzato (Roma, 3-4 Dicembre 2009), ISPRA, Roma, 257-281. 
Cremonini, S. (2010b). Can subaerial pockmarks exist?, In: Atti del $2^{\circ}$ Workshop internazionale "I sinkholes. Gli sprofondamenti catastrofici nell'ambiente naturale ed in quello antropizzato" (Roma, 3-4 dicembre 2009), ISPRA, Roma, 29-34.

Cremonini, S., L. Martelli and A. Zanutta (2010). An initial approach to the analysis of alluvial plain sinkhole-clusters at Finale Emilia and Reno Finalese (Modena - Italy), Atti del $2^{\circ}$ Workshop internazionale "I sinkholes. Gli sprofondamenti catastrofici nell'ambiente naturale ed in quello antropizzato" (Roma, 3-4 dicembre 2009), ISPRA, Roma, 453-468.

Crespellani, T., J. Facciorusso, A. Ghinelli, C. Madiai, S. Renzi and G. Vannucchi (2012). Rapporto preliminare sui diffusi fenomeni di liquefazione verificatisi durante il terremoto in pianura padana emiliana del 31 maggio 2012, Technical report, Università di Firenze, Dipartimento di Ingegneria Civile e Ambientale - Sezione geotecnica.

ENI (1972). Acque dolci sotterranee. Inventario dei dati raccolti dall'AGIP durante la ricerca di idrocarburi in Italia, Roma, 914 pp.

Fioravante, V., and D. Giretti (2012). Il caso di Sant'AgostinoSan Carlo. 6 giugno 2012, Technical report, Università di Ferrara, Dipartimento di Ingegneria.

Galli, P. (2000). New empirical relationships between magnitude and distance for liquefaction, Tectonophysics, 324, 169-187.

Galli, P., S. Castenetto and E. Peronace (2012). May 2012 Emilia earthquakes $\left(\mathrm{M}_{\mathrm{W}} 6\right.$, northern Italy): macroseismic effects distribution and seismotectonic implications, Alpine and Mediterranean Quaternary, 25, in press; available at: http:/amq.aiqua.it

Gruppo Lavoro Liquefazione (2012). Primo rapporto sugli effetti della liquefazione osservati a S. Carlo, frazione di S. Agostino (Provincia di Ferrara), A cura del gruppo di lavoro per la valutazione degli effetti di liquefazione a seguito dei terremoti del 20 e 29 maggio 2012 (Regione Emilia-Romagna, PG.2012.0134978 del 31/5/2012).

INGV (2012a). http:/ / cnt.rm.ingv.it/

INGV (2012b). http:/ / terremoti.ingv.it/images/pdf/ / Report _20120720_0545.pdf

INGV (2012c). http:/ / ingvterremoti.files.wordpress.com/ 2012/05/animazione22.gif

ISPRA and R.ER. (2009). Note illustrative della Carta Geologica d'Italia alla Scala 1:50.000, Foglio 203 - Poggio Renatico, U. Cibin and S. Segadelli (eds.), Roma, 104 pp.

Martinelli, G., A. Minissale and C. Verrucchi (1998). Geochemistry of heavily exploited aquifers in the Emilia-Romagna region (Po Valley, northern Italy), Environm. Geol., 36, 195-206.

Martinelli, G. (2007). Attività degassanti nella Regione Emilia-Romagna, In: Il radon ambientale in Emilia Romagna, Servizio Sanitario Regionale Emilia-Romagna,
Bologna, 51, 57-62.

Martinelli, G., S. Cremonini and E. Samonati, (2012). Geological and geochemical setting of natural hydrocarbon emissions in Italy, In: Hamid A. Al-Megren (ed.), Advances in Natural Gas Technology, 79-120; available at: http://www.intechopen.com/articles/show/title/geolo gical-and-geochemical-setting-of-natural-hydrocarbonemissions-in-italy

MSU (Moscow State University) (2011). RadExPro QC, 2011.4b version; available at: www.radexpro.com

Obermeier, S.F., E.C. Pond and S.M. Olson (2001). Paleoliquefaction studies in continental settings: geologic and geotechnical factors in interpretations and back-analysis, U.S. Geological Survey open-file Report 01-29-2001; available at: https:// netfiles.uiuc.edu/tstark/website/Confe rence_Publications/CP45.pdf)

Pellegrini, M., A. Colombetti and A. Zavatti (1976). Idrogeologia profonda della pianura modenese, Quaderni dell'Istituto di Ricerca sulle Acque, 28, 213-243.

Pellegrini, M., and L. Vezzani (1978). Faglie attive in superficie nella Pianura Padana presso Correggio (Reggio Emilia) e Massa Finalese (Modena), Geogr. Fis. Din. Quat., 1, 141-149.

Picotti, V., and F.J. Pazzaglia (2008). A new active tectonic model for the construction of the northern Apennines mountain front near Bologna (Italy), J. Geophys. Res., 113, BO8412; doi:10.1029/2007JB005307.

Puppini, G., V. Boschi, C. Frassoldati and Co. L. Dal (1955). Le terre salse del comprensorio di Burana e la loro bonifica pedologica, Stazione Sperimentale Agraria, Modena.

Ramsey, J.G. (1967). Folding and fracturing of rocks, McGraw-Hill, New York.

Salvi, S., C. Tolomei, J.P. Merryman Boncori, G. Pezzo, S. Atzori, A. Antonioli, E. Trasatti, R. Giuliani, S. Zoffoli and A. Coletta (2012). Activation of the SIGRIS monitoring system for ground deformation mapping during the Emilia 2012 seismic sequence, using COSMO-SkyMed InSAR data, Annals of Geophysics, 55 (4); doi:10.4401/ag6181.

Scicli, A. (1972). L'attività estrattiva e le risorse della regione Emilia-Romagna, Modena 1972, 736 pp.

Sibson, R.H. (1981). Fluid flow accompanying faulting: field evidence and models, In: D.W. Simpson and P.G. Richards (eds.), Earthquake Prediction: An International Review, AGU Maurice Ewing Series 4, 593-603.

\footnotetext{
${ }^{\star}$ Corresponding author: Lisa Borgatti,

Università di Bologna, Dipartimento di Ingegneria Civile, Ambientale e dei Materiali (DICAM), Bologna, Italy; email: lisa.borgatti@unibo.it.

(C) 2012 by the Istituto Nazionale di Geofisica e Vulcanologia. All rights reserved.
} 